\title{
Estimation of the Rationality of ARV Therapy in South India
}

\author{
Pragna Malavika Bugge ${ }^{1 *}$, Rajaiah Thangaraj Saravana Kumar² and Lakshmi B. V. S. ${ }^{3}$ \\ 'Assistant Professor, Department of Pharmacy Practice, NOVA College of Pharmaceutical Education and Research, \\ JNTUK, Vijayawada - 521456, Andhra Pradesh, India; pragnamalavika777@gmail.com \\ ${ }^{2}$ Associate Professor, Department of Pharmacy Practice, Annamalai University, \\ Chidambaram - 608002, Tamil Nadu, India \\ ${ }^{3}$ Associate Professor, Department of Pharmacy, Mallareddy College of Pharmacy, \\ Osmania University, Hyderabad - 500007, Telangana, India
}

\begin{abstract}
The main objective of the present study was to perform and improve the rationality by looking for potential Drug-Drug Interactions and Adverse Drug Reactions associated with Anti-Retroviral Therapy and increase the adherence among Human Immunodeficiency Virus (HIV) patients attending to the Anti-Retroviral Therapy (ART) centre in south India. A prospective observational study was conducted in the city of Vijayawada, South India to assess the Adverse Drug Reactions (ADR's) and Drug-Drug interactions (DDI's) among the patients receiving Highly Active Anti RetroviralAnti-Retroviral Therapy (HAART) using approved scales and databases. A total of 530 patients were screened in a span of 1 year, resulting in 394 ADR's and 385 DDI's among the various drugs being used.The most commonly used drug combination was Tenofivir + Lamivudine + Efavirenz (63.3\%). In looking at the reported ADR's the majority of them were mild in terms of severity, preventability and causality and none of the DDI's were severe enough to bring a change in the therapy. Statistical analysis was performed using SPSS 16 version by using Chi-square test. The risk caused by the associated ADR's and DDI's are observed and proven to be not deleterious in most of the cases. If adequate knowledge, prompt treatment and in-depth analysis of the associated risk factors and personal history were considered the HAART would be definitely more successful.
\end{abstract}

Keywords: Human Immunodeficiency Virus

\section{Introduction}

Human Immunodeficiency Virus (HIV-1) is a serious health problem $^{1}$ occurring worldwide with estimated number of around 38 million living with it by 2019 , among which 1.7 million were new occurences ${ }^{2}$. This perception about the condition has changed drastically in developed countries from the time HAART introduction in the last part of the '90s. The therapy has proven a remarkable decrease in AIDS-related mortality and made this rapidly fatal syndrome into manageable infection ${ }^{1}$. Viral burden and the CD4 cell count are always maintained under control by regulating the virus replication and maintaining the $\mathrm{CD} 4$ cell count ${ }^{3}$.

However, the clinical advantages seen from HAART don't appear to be totally unbiased, as they are related with undesirable impacts called Adverse Drug Reactions (ADRs). An ADR is any response which is harmful or undesirable, happened as the result of a drug's. The HAART is accompanied by multiple various unwanted ADR's, which limits their open usage them. This has forced the Health Care Professionals (HCP) either to

${ }^{*}$ Author for correspondence 
alter the drug, dosage, combination or even withdrawal ${ }^{4}$. Pertaining to compromised immune system, HIV patients are at risk of co-morbidities; these adverse events/ reactions associated from the therapy had significantly impacted the adherence and directly or indirectly leading to treatment failure ${ }^{5}$.

To identify and substitute the offending drug is quite cumbersome and at times impossible as most HAART regimens do exist in Fixed-Dose Combinations (FDC) of different classes, most of which are first-line drug. The pace of treatment failure due to the advancement of unwanted reactions is far more significant and almost incomparable in resource limited settings ${ }^{2}$. As such the availability of Resources and Ethical concerns are the two main hurdles for the success and invention of new drugs into the market. These issues are making the road narrow ahead for HIV patients. More so, the inexistence of adequate drug toxicity monitoring and reporting schemes ${ }^{6}$, underestimates the burden of HAART associated ADRs by underreporting and no proper signal generation.

HAART is highly associated with potential drug-drug interactions (PDDIs) attributed to polypharmacy linked to age, gender and occurrence of multiple complications ${ }^{z}$ among the known therapeutic classes of drugs antiretroviral (ARV) drugs are the most noteworthy class known for potential drug-drug interactions. Notably, the drug classes Protease inhibitors (PI's) and non-nucleotide reverse transcriptase inhibitors (NNRTI's) lead the race as they undergo extensive metabolism through cytochrome P450 enzyme ${ }^{8}$. The probability of DDI's is further escalated by the usage of OTC (over-the-counter) drugs, self-medication, and herbal medicines etc., which mostly go unnoticed ${ }^{9}$. Drug interactions might be associated with a substantial risk for toxicity, decreased efficacy and subsequent emergence of drug resistance and also lead to treatment failure directly. Therefore, proper identification, management and prevention of such unwanted drug interactions are crucial for patient care and treatment success ${ }^{10}$. Previous studies have indicated that PDDIs in HIV therapy are common, ranging from 23 to $41 \%^{10-13}$; however, most of them were performed retrospectively by medical chart or pharmacy record reviews, and thus might have underestimated the prevalence of PDDIs as the complete medication history is thoroughly documented ${ }^{9-12}$. In addition, some of these studies were done in limited sample population, which might prevent them from applying to the general population.

Given these concerns and to know and understand the condition of HAART in South India, we prospectively conducted a hospital-based study in the Government
General Hospital, Vijayawada. We are looking ahead to find any common ADR's and the PDDI's associated with the HAART.

\section{Method}

A community-based Prospective, observational study was carried out for a period of 1 year (September 2018August 2019) in ART clinic, Old Government General Hospital (GGH), located in Vijayawada, South India. The clinic was held all during the week days; where many HIV positive patients around the state receive antiretroviral therapy (ART) throughout the year. This center maintains computer-based clinical data of all the patients receiving ART which includes, anthropometric details, medication history, patient response to the drugs, duration of therapy, co-morbidities and associated medication etc., The ARV (antiretroviral) drugs are dispensed free of charge, monthly, to about 4,000 registered HIV infected patients including men, pregnant and non-pregnant women, and children from different parts of the Andhra Pradesh state. Institutional ethics committee approval was taken before the initiation of the study and written informed consent (preferred local language) was obtained from all subjects before their inclusion. Confidentiality of information was duly maintained and basic principles of ethics in were strictly followed. The primary outcome of interest is looking after the ADR's and secondary being the DDI's reported. All consecutive treatment subjects of either gender aged 18 years or above, on ART, co-medications for opportunistic infections and concurrent diseases, as well as medications used for symptomatic relief, herbals and recreational drugs were included. Subjects having complications, treatment modifications, immunologic failure, pregnant women, lactating mothers were excluded from the study. Data regarding patient demographics and clinical information were collected in a pre-structured pro forma both from direct interview and the automated medical database.

ADR diagnosis was based on patient complaints and physician confirmed events (if any) during routine clinical examination. ADRs reported were subsequently followed up. We have followed the standards laid by Pharmacovigilance Program of India (PvPI) in obtaining the adverse events, their occurrence, history and other relevant information from the case sheets and the physician notes. To improve the accuracy of our investigations we have done the individual causality assessment using the Naranjo's scale of causality assessment $t^{\frac{14}{4}}$, which classified the interactions to definite, probable, possible and doubtful. Seriousness of the ADR was surveyed utilizing ADR Severity Assessment Scale (Modified Hartwig and 
Siegel $)^{15}$ - which classify the ADR into mild, moderate and severe. Preventability of the ADR was performed by Schumock and Thornton scale ${ }^{16}$ which groups the ADRs into definitely preventable, presumably preventable and not preventable. The ADR's reported were organized based on the organ system in our previous work ${ }^{17}$, and now we focus at scaling them.

For assessing Drug-Drug Interactions, the University of Liverpool drug interaction database ${ }^{18}$ was followed with additional assessment by two other specialists in the department of Pharmacology. This database highlights the interactions of the HIV drugs to other HIV and non-HIV drugs and suggests appropriate alternatives and categorizes the seriousness of the interaction into three areas: Serious interaction for drugs that should not be co-administered, moderate interaction indicating requiring of dosage modification or close monitoring and mild/no interaction which represents no known or anticipated interaction and doesn't prompt any change. The results gave us a summary of the PDDIs as well as a recommendation for the management of them. The obtained information was taken to the clinicians for promptness and necessary action. Descriptive statistical analysis of the obtained data was performed, reviewed, authorized and analyzed using SPSS software 21 version.

\section{Results}

A total of $530 \mathrm{HIV}$ patients, who satisfied the study criteria were enrolled, their data was collected both from personal interview and from the hospital records. The socio demographic data was recorded and the majority of the HIV patients were found to be females with $52.6 \%$, in the age group between 18 and 28 years. The major portion of the individuals has less education and are married (Table 1). The therapy includes around 11 varied combination of ART drugs; however, we have included only the top three combinations and they contributed for around $95 \%$ of population receiving ART (Table 2). Highest prescribed regimen was found to be the combination of Tenofovir, Lamivudine and Efavirenz (TAF/3TC/EFV) reaching to around $60 \%$.

These three drug combinations were closely monitored for the primary and secondary outcomes. A total of 394 ADR's and 385 DDI's were found in these combinations of drugs. The ADR's were assessed for the severity, preventability and causality and found that $88 \%$ were mild $94 \%$ can be definitely preventable and $89 \%$ to be in possible range respectively (Table 3 ). In looking at the Potential Drug-Drug Interactions (PDDI's), older age population had more than one DDI's compared to other age groups. The interactions between the HIV drugs and other recreational or herbal drugs were not looked. Among the various drug interactions; the interaction between Efavirenz + Midazolam and Zidovudine + Ribavirin were found to be the serious interaction. Moderate interactions contribute for around $85 \%$ of the total DDI's which can be definitely controlled by proper care (Table 4 ).

Table 1. Socio demographic characters of HIV patients

\begin{tabular}{|c|c|c|}
\hline Variable & $\begin{array}{c}\text { Frequency } \\
(\mathrm{N}=530)\end{array}$ & Percentage $\%$ \\
\hline \multicolumn{3}{|c|}{ Gender } \\
\hline Male & 250 & 47.1 \\
\hline Female & 278 & 52.6 \\
\hline Others & 2 & 0.3 \\
\hline \multicolumn{3}{|c|}{ Age (Years) } \\
\hline $18-28$ & 141 & 26.6 \\
\hline $29-38$ & 125 & 23.5 \\
\hline $39-48$ & 120 & 22.7 \\
\hline $49-58$ & 122 & 23.1 \\
\hline$\geq 59$ & 22 & 4.1 \\
\hline \multicolumn{3}{|c|}{ Educational status } \\
\hline None & 157 & 29.7 \\
\hline Primary & 194 & 36.5 \\
\hline Secondary & 114 & 21.6 \\
\hline $\begin{array}{l}\text { Post- } \\
\text { secondary }\end{array}$ & 65 & 12.2 \\
\hline \multicolumn{3}{|c|}{ Marital status } \\
\hline Married & 311 & 76.1 \\
\hline Unmarried & 51 & 11.7 \\
\hline Widow & 13 & 5 \\
\hline Divorced & 11 & 2.2 \\
\hline Separated & 31 & 3.9 \\
\hline Unreported & 13 & 6.1 \\
\hline
\end{tabular}


Table 2. Prescribed ARV drug combinations and associated ADR's

\begin{tabular}{|l|l|l|l|}
\hline \multicolumn{1}{|c|}{$\begin{array}{c}\text { Antiretroviral drug } \\
\text { combination }\end{array}$} & $\begin{array}{c}\text { Number and percentage } \\
\text { of Patients 530(\%) }\end{array}$ & $\begin{array}{c}\text { Number and percentage of } \\
\text { ADR's occurred 394(\%) }\end{array}$ & \multicolumn{1}{|c|}{ P value } \\
\hline TAF /3TC / EFV & $335(63.3)$ & $235(59.6)$ & $<0.05$ \\
\hline ZVD/ 3TC / NVP & $137(25.8)$ & $97(24.6)$ & $<0.05$ \\
\hline ZVD/ 3TC / EFV & $20(3.7)$ & $21(5.32)$ & $<0.05$ \\
\hline
\end{tabular}

${ }^{\star}$ Tenofivir (TAF), Lamivudine (3TC), Efavirenz (EFV), Nevirapine (NVP), Zidovudine (ZVD)

Table 3. Assessing ADR's for causality, severity and preventability

\begin{tabular}{|c|c|c|c|}
\hline \multicolumn{3}{|c|}{ Naranjo's Causality assessment scale } & \multirow[t]{2}{*}{$P$ value } \\
\hline Possible Number (\%) & Probable Number (\%) & Definitive Number (\%) & \\
\hline $351(89.3)$ & $28(7.7)$ & None & $<0.05$ \\
\hline \multicolumn{3}{|c|}{ Modified Hartwig's\& Siegel severity scale } & \\
\hline Mild Number (\%) & Moderate Number (\%) & Severe Number (\%) & \\
\hline $348(88.2)$ & $44(11.1)$ & $3(0.7)$ & $<0.05$ \\
\hline \multicolumn{3}{|c|}{ Schumonk\& Thornton Preventability scale } & \\
\hline $\begin{array}{c}\text { Definitely preventable } \\
\text { Number }(\%)\end{array}$ & $\begin{array}{c}\text { Probably preventable } \\
\text { Number }(\%)\end{array}$ & $\begin{array}{c}\text { Not preventable } \\
\text { Number (\%) }\end{array}$ & \\
\hline $365(92.7)$ & $29(7.3)$ & None & $<0.05$ \\
\hline
\end{tabular}

Table 4. DDI's associated with the HIV and non-HIV drugs

\begin{tabular}{|c|c|c|c|c|c|}
\hline \multicolumn{6}{|c|}{ SEVERE INTERACTIONS } \\
\hline DRUG A & DRUG B & $\begin{array}{l}\text { Description of } \\
\text { the interaction }\end{array}$ & Number & Percentage & Intervention \\
\hline Efavirenz & Midazolam & $\begin{array}{l}\text { Risk of prolonged } \\
\text { sedation, respiratory } \\
\text { depression }\end{array}$ & 3 & $<1$ & $\begin{array}{l}\text { Discontinued } \\
\text { midazolam }\end{array}$ \\
\hline Zidovudine & Ribavirin & $\begin{array}{c}\text { Exacerbation } \\
\text { of anemia and } \\
\text { hepatic enzymes } \\
\text { decompensation, }\end{array}$ & 1 & $<1$ & $\begin{array}{l}\text { Close monitoring, } \\
\text { high alert }\end{array}$ \\
\hline \multicolumn{6}{|c|}{ MODERATE INTERACTIONS } \\
\hline DRUG A & DRUG B & $\begin{array}{l}\text { Description of } \\
\text { the interaction }\end{array}$ & Number & Percentage & Intervention \\
\hline $\begin{array}{l}\text { NNRTI's \& } \\
\text { NRTI's }\end{array}$ & $\begin{array}{l}\text { Lipid lowering } \\
\text { drugs }\end{array}$ & $\begin{array}{l}\text { Predominantly } \\
\text { decreases the effect of } \\
\text { statins; mixed effect. }\end{array}$ & 76 & 20 & $\begin{array}{l}\text { Dosage adjustment } \\
\text { for statins, monitor } \\
\text { serum drug } \\
\text { concentrations }\end{array}$ \\
\hline
\end{tabular}




\begin{tabular}{|c|c|c|c|c|c|}
\hline & $\begin{array}{l}\text { Anxiolytics/ } \\
\text { sedatives }\end{array}$ & $\begin{array}{l}\text { Predominantly } \\
\text { decreases the effect } \\
\text { of anxiolytics and } \\
\text { sedatives; mixed } \\
\text { effect. }\end{array}$ & 17 & 5 & $\begin{array}{l}\text { Dosage adjustment } \\
\text { for precipitant } \\
\text { drug, monitor } \\
\text { serum drug } \\
\text { concentrations }\end{array}$ \\
\hline & $\begin{array}{l}\text { Calcium } \\
\text { channel } \\
\text { blockers }\end{array}$ & $\begin{array}{l}\text { Predominantly } \\
\text { decreases the effect } \\
\text { of calcium channel } \\
\text { blockers; mixed } \\
\text { effect. }\end{array}$ & 52 & 14 & $\begin{array}{l}\text { Dosage adjustment } \\
\text { for precipitant } \\
\text { drug, monitor } \\
\text { serum drug } \\
\text { concentrations }\end{array}$ \\
\hline & $\begin{array}{l}\text { Narcotic } \\
\text { Analgesics }\end{array}$ & $\begin{array}{l}\text { Slightly decreases } \\
\text { the concentrations of } \\
\text { narcotic analgesics; } \\
\text { mixed effect. }\end{array}$ & 56 & 15 & $\begin{array}{l}\text { Monitor drug } \\
\text { concentrations }\end{array}$ \\
\hline & $\begin{array}{l}\text { Anti- } \\
\text { depressants }\end{array}$ & $\begin{array}{l}\text { Further studies } \\
\text { are required; few } \\
\text { evidences of NNRTI's } \\
\text { decreasing the levels } \\
\text { of antidepressant } \\
\text { exist; mixed effect. }\end{array}$ & 96 & 25 & $\begin{array}{l}\text { Monitor the } \\
\text { depressive action, } \\
\text { rule out other } \\
\text { confounding } \\
\text { parameters }\end{array}$ \\
\hline & $\begin{array}{l}\text { Anti- } \\
\text { convulsants }\end{array}$ & $\begin{array}{l}\text { Predominantly } \\
\text { decreases the } \\
\text { effect of NNRTI's } \\
\text { leading to treatment } \\
\text { failure. Often } \\
\text { contraindicated. }\end{array}$ & 11 & 3 & $\begin{array}{l}\text { Discontinue the } \\
\text { drug, if required } \\
\text { switch for } \\
\text { alternatives. }\end{array}$ \\
\hline & & MILD/NO & NTERACTIO & & \\
\hline DRUG A & DRUG B & $\begin{array}{l}\text { Description of } \\
\text { the interaction }\end{array}$ & Number & Percentage & Intervention \\
\hline NNRTI's & $\begin{array}{l}\text { Calcium } \\
\text { channel } \\
\text { blockers, } \\
\text { aspirin, }\end{array}$ & No interaction & 79 & NA & NONE \\
\hline Nevirapine & $\begin{array}{l}\text { Diclofena, } \\
\text { celecoxib, } \\
\text { morphine, } \\
\text { naproxen, } \\
\text { levitiractam }\end{array}$ & No interaction & 135 & NA & NONE \\
\hline NRTI's & $\begin{array}{l}\text { Calcium } \\
\text { channel } \\
\text { blockers, statin }\end{array}$ & No interaction & 56 & NA & NONE \\
\hline
\end{tabular}

${ }^{*}$ NNRTI'S: Non-nucleotide reverse transcriptase inhibitors, NRTI'S: Nucleotide reverse transcriptase inhibitors, NA: Not Applicable

\section{Discussion}

The present study was aimed at evaluating the incidence of ADR's and the DDI's among the patients receiving ARV drugs at the ART center, Vijayawada. Our findings show that about 2 in every 5 patients (40.2\%) on HAART, reported at least ADR. This is in contradiction with findings in an Indian study of 400 patients on HAART, where the prevalence of ADRs was 17.5\% $\frac{19}{}$ and was in accordance with a study in Kenya where HAART-related ADRs were present in $40.6 \%$ of patients ${ }^{20}$. This can be viewed as the difference in reporting structure of ADR's, treatment and the patient's socio-demographics ${ }^{6}$. Among 
the reported ADR's majority were ought to be possible and if possible are mild and are usually in definitely preventable range. No ADR reported in our study are significant, requiring a treatment change. We haven't preferred looking for Dechallenge and Rechallenge.

Tenofivir + Lamivudine + Efavirenz (63.3\%) was highly prescribed ARV combination and was in consistent with the guidelines of WHO and the national guidelines for the use of ARV drugs in India ${ }_{2,21}$ this was in accordance with a study conducted in Allahabad ${ }^{22}$ to around (66.4\%). While in another study conducted at Nigeria, the same combination is highly prescribed while replacing Efavirenz with Zidovudine ${ }^{23}$. As expected, the risk for DDIs increased with increase in the number of co-medications - polypharmacy ${ }^{\underline{T}}$, the majority of identified DDIs occurred between the two most commonly prescribed HIV drug categories including NNRTI- or NRTI- and CNS- (32\%) or CVS (34\%) drugs which are the two most commonly prescribed non-HIV drug categories. The high proportion of these non-HIV drugs is explained by the fact that the patients were suffering with anxiety, depression, fear and insecurity pertaining to majorly social beliefs representing a considerable part among the HIV-infected population ${ }^{24}$. Cardiovascular drugs result from the various risk factors associated with occurrence of the associated cardiovascular diseases ${ }^{25}$. Most of the documented DDIs was moderate in nature and required a potential dose adjustment or close monitoring to minimize unwanted clinical consequences.

Polypharmacy was more frequent in older or obese patients as a consequence of increased risk for various conditions, mainly cardiovascular diseases and in patients with $\mathrm{HCV}$ infection ${ }^{26-27}$. The goal of ADR observation, monitoring their severity and assessing the potential DDI's was to early recognize, minimize or antagonize the impact to increase compliance and quality of care. The knowledge of various factors pertaining to DDIs will help clinicians to either minimize or prevent them. The establishment of a comprehensive interaction alert system will promote particular attention in terms of drug prescription and drug interaction screening.Efficient and solid surveillance methods including organized Pharmacovigilance system is definitely the need of the hour. However, such databases come with certain disadvantages including discrepancies between databases ${ }^{28}$, the reliability is exceptionally subjected to regularity in updates and the significance of the interaction. In addition, most of the databases provide data only between two drugs, whereas ART is often the combination of multiple drugs that commonly interact. Of course, the interaction observed might not always turn into a real interaction, pertaining to inter-subject variability and genetic makeup; often the major issue of under-reporting. Linked to poor resource settings, affordability and unavailability of alternate drug combinations the management of DDI's is quite problematic ${ }^{29}$.

In summary, the associated occurrence of DDI's and ADR's has made the HAART therapy not fully successful, which is also linked to ageing population and occurrence of co-morbidities. However, the major portion of these can be resolved if prompt care is provided with proper monitoring and attention towards the dosage adjustments and interacting drug's, which was observed in our study. For which, availability of a standard database, clinician's self-education about interacting drugs, the knowledge of a patient's complete drug regimen and the risk factors associated with DDIs are crucial.

\section{References}

1. Mocroft A,Vella S, Benfield TL, Chiesi A, Miller V, Gargalianos Pet al. Changing patterns of mortality across Europe in patients infected with HIV-1 EuroSIDA Study Group. Lancet. 1998; 352(9142): 1725-30. https://doi.org/10.1016/S0140-6736(98)032 $01-2$

2. UNAIDS. Report on the global HIV/AIDS epidemic 2008: Joint United Nations Programme on HIV/AIDS. Available on https://www.unaids.org/ en/resources/fact-sheet

3. Ledergerber $\mathrm{BM}$, et al. Clinical progression and virological failure on highly active antiretroviral therapy in HIV-1 patients: a prospective cohort study - Swiss HIV Cohort Study. Lancet. 1999; 353(9156): 86 3-8. https://doi.org/10.1016/S0140-6736(99)01122-8

4. Edwards IR and JK Aronson. Adverse drug reactions: definitions, diagnosis, and management. Lancet. 2000; 356(9237):1255-9.https://doi.org/10.1016/S0140-673 6(00)02799-9

5. Domingo $\mathrm{P}$ and F Lozano. Management of anti retroviral drug toxicity. EnfermedadesInfecciosasy MicrobiologiaClinica. 2011; 29(7):535-44. https:// doi.org/10.1016/j.eimc.2010.12.001

6. WHO/Forum for collaborative HIV Research Joint Meeting, ARV drugs adverse events, case definition, grading, laboratory diagnosis and treatment monitoring, February 28-29, 2008. Geneva, Switzerland. Available on http://www.hivforum.org/index.php?option =com_content\&task=view\&id=59\&Itemid=102 
7. Simone MJ, Appelbaum J. HIV in older adults. Geriatrics. 2008; 63(12): 6-12.

8. Barry M, Mulcahy F, Merry C, Gibbons S, Back D. Pharmacokinetics and potential interactions amongst antiretroviral agents used to treat patient with HIV infection. Clin Pharmacokinet. 1999; 36(4):289304.https://doi.org/10.2165/00003088-199936040-00 004

9. Furler MD, Einarson TR, Walmsley S, Millson M, Bendayan R. Polypharmacy in HIV: impact of data source and gender on reported drug utilization. AIDS Patient Care STDS 2004; 18(10): 568-586. https://doi.org/10.1089/apc.2004.18.568

10. Park-Wyllie LY, Levine MA, Holbrook A,Thabane $\mathrm{L}$, Antoniou T, Yoong D, et al. Outcomes of dosage adjustments used to manage antiretroviral drug interactions. Clin Infect Dis. 2007; 45(1): 933-936. https://doi.org/10.1086/521252

11. Shah S, McGowan J, Opulski B, Lieblein A, Saperstein A. Identification of drug interactions involving antiretroviral therapy (ART) in New York City HIV specialty clinics. 14th Conference on Retroviruses and Opportunistic Infections. 25-28 February 2007, Los Angeles, CA, USA.

12. de Maat MMR, de Boer A, Koks CH, Mulder JW, Meenhorst PL, van Gorp EC,et al. Evaluation of clinical pharmacist interventions on drug interactions in outpatient pharmaceutical HIV-care. J Clin Pharm Ther.2004;29(2):121-130.https://doi.org/10.1111/j.13 65-2710.2003.00541.x

13. Miller CD, El-Kholi R, Faragon JJ, Lodise TP. Prevalence and risk factors for clinically significant drug interactions with antiretroviral therapy. Pharmacotherapy 2007; 27(10): 1379-1386. https://do i.org/10.1592/phco.27.10.1379

14. Naranjo CA, Busto U, Sellars EM, Sandor P, Ruiz I, Roberts EA and Janecek E. Method for Estimating the Probability of Adverse Drug Reactions. Clin Pharmacol Ther. 1981; 30(2): 239-45. https://doi.org/10.1038/clpt.1981.154

15. Hartwig SC, Siegel J, Schneider PJ. Preventability and severity assessment in reporting adverse drug reactions. Am J Hosp Pharm. 1992; 49(9): 2229-32. https://doi.org/10.1093/ajhp/49.9.2229
16. Schumock GT, Thornton JP. Focusing on the preventability of adverse drug reactions. Hosp Pharm. 1992; 27(6): 538

17. Malavika BP, Kumar RTS, Lakshmi BVS. Pharmacoepidemiology of antiretroviral drugs in a tertiary care teaching hospital. J Glob Phar Tech. 2020; 12(07): 01-07.

18. Liverpool HIV drug interactions. Available on http:// www.hiv-druginteractions.org

19. Modayil RR, A Harugeri, G Parthasarathi, M Ramesh, R Prasad, V Naik, et t.,al. Adverse drug reactionstoantiretroviraltherapy(ART):an experience of spontaneous reporting and intensive monitoring from ART centre in India. Pharmacoepidemiology and drug safety. 2010; 19(3): 247-55. https://doi.org /10.1002/pds. 1907

20. Hawkins C, C Achenbach, W Fryda, D Ngare, and R Murphy. Antiretroviral durability and tolerability in HIV-infected adults living in urban Kenya. J. Acquir. Immune Defic. Syndr. 2007; 45(3): 304-10. https://doi.org/10.1097/QAI.0b013e318050d66c

21. National AIDS Control Organization Ministry of Health and Family Welfare Government of India. National technical guidelines on retroviralantiretroviral treatment. 2018.

22. Bandyopadhyay A, Chaurasia RC, Palepu S, Yadav RK. A study of adherence to antiretroviral therapy in a tertiary care hospital at Allahabad, India. Indian J Sex Transm Dis AIDS. 2019; 40(1): 46-50. https:// doi.org/10.4103/ijstd.IJSTD_81_17

23. Oreagba LA, Usman SO, Olayemi SO, Oshikoya KA, Opanuga O, Adeyemo TA, et.,al. Pharmacoepidemiology of antiretroviral drugs in a teaching hospital in Lagos, Nigeria. Ghana Med J. 2014; 48(4): 194-203. https://doi.org/10.4314/gmj.v4 $8 \mathrm{i} 4.5$

24. Meade CS, Sikkema KJ. HIV risk behaviour among adults with severe mental illness: a systematic review. Clin Psychol Rev 2005; 25(4): 433-457. https:// doi.org/10.1016/j.cpr.2005.02.001

25. The Data Collection on Adverse Events of Anti-HIV Drugs (DAD) Study Group. Combination antiretroviral therapy and the risk of myocardial 
infarction. NEngl J Med 2003; 349: 1993-2003.https:// doi.org/10.1056/NEJMoa030218

26. d'ArminioMonforte A, Cozzi-Lepri A, Castagno A,Antinori A, De Luca A, Mussini C,et al. Risk of developing specific AIDS defining illnesses in patients co-infected with HIV and hepatitis $C$ virus with or without liver cirrhosis. Clin Infect Dis 2009; 49(4): 612-622. https://doi.org/10.1086/603557

27. Mohsen AH, Murad S, Easterbrook PJ. Prevalence of hepatitis $\mathrm{C}$ in an ethnically diverse HIV-1-infected cohort in south London. HIV Med 2005; 6(3):206-
215. https://doi.org/10.1111/j.1468-1293.2005.00291 . $\mathrm{x}$

28. Pham PA. Drug-drug interaction programs in clinical practice. Clin Pharmacol Ther 2008; 83(3): 396-398. https://doi.org/10.1038/sj.clpt.6100504

29. Dooley KE, Flexner C, Andrade AS. Drug interactions involving combination antiretroviral therapy and other anti-infective agents: repercussions for resource-limited countries. J Infect Dis 2008; 198(7): 948-961.https://doi.org/10.1086/591459 